\title{
MAYORITASISME DAN MINORITASISME
}

Oleh Shohibul Anshor siregar

Jum'at pekan lalu (5 Mei 2017) Muhammad Najib Burhani dari LIPI memulai paparannya dalam sebuah Focus Group Discussion di UMSU Medan dengan mengutip pernyataan Saba Mahmood dalam bukunya "Religious freedom: the minority question, and geopolitics in the Middle East" (2012, p 433). Di sekitar Timur Tengah, begitu kata Saba Mahmood, jaminan konstitusi atas kebebasan beragama adalah instrumen yang sangat penting bagi para misionaris dan lembaga-lembaga tempat mereka bekerja. Dengan itulah mereka beroleh keleluasaan untuk melakukan Kristenisasi di kalangan umat Islam dan orang Koptik. Konversi keagamaan (murtad), bagi mereka, bukanlah sesuatu yang perlu diatur oleh hukum positif, merujuk kepada hak asasi yang dijunjung tinggi.

Hal-hal seperti ini jarang disadari. Di antara mereka yang mengklaim bekerja sebagai ilmuan pun selama ini tidak banyak yang mau berfikir sejujur Saba Mahmood. Tetapi itulah faktanya, bahwa isu minoritas dalam wacana tentang kebebasan beragama itu hanyalah ekspresi keinginan kuat untuk melindungi non-Muslim dan kepentingan Barat di dunia Islam. Buruk tidaknya keadaan itu adalah bagian yang harus dicatat sebagai kemenangan demokrasi liberal-sekular yang menempatkan Negara pada posisi netral, terutama dalam mengatasi dan memerlakukan kelompok agama yang berbeda dari mayoritas.

Tetapi jangan pernah terkecoh, prinsip ini bukanlah hal yang harus dipercaya sebagai bagian dari ajaran tentang hak asasi manusia. Tidak sama sekali. Muhammad Najib Burhani menambahkan kutipannya dari Saba Mahmood bahwa bahwa "far from being a secular instrument of state neutrality, was for these advocates closely woven with their desire to win Christian converts" (Saba Mahmood, 2012, p 433). Jauh dari hakekat instrumen ajaran yang bersumber dari gagasan sekuler netralitas Negara, sesungguhnya agenda terselubungnya ialah keinginan untuk memenangkan orang-orang Kristen di wilayah berpenduduk mayoritas muslim. Wujud nyata scenario itu ialah intervensi asing atas --atau bahkan lebih tepat dikatakan sebagai sebuah pelanggaran berat terhadap-- kedaulatan negeri muslim (terutama dalam kasus Mesir) yang sesungguhnya bertolak belakang dengan hakekat International Religious Freedom Act.

Bagaimana di Indonesia? Agaknya masalah mayoritas dan minoritas itu adalah sebuah isu politik yang begitu sensitif hingga melahirkan semacam ideologi baru yang akhirnya menjelmakan pandangan-pandangan praksis yang tak urung memicu pertikaian pendapat yang dahsyat. Ia berlapis-lapis dalam selimut-selimut pembalut yang ketat seperti kueh ombus-ombus kecil dari Siborong-borong yang berbungkus lembaran-lembaran daun pisang hingga kelihatan begitu besar. Pemuncakan isyu mayoritas vs minoritas itu tak urung menerpa dunia politik hingga Presiden RI pun belum lama ini seolah berkata "beragamalah tetapi tinggalkan jauh-jauh agamamu ketika berpolitik". Sayangnya tidak ada yang mengingatkan Presiden bahwa salah satu partai yang mendukung pasangan yang beliau dukung untuk DKI dan kalah, adalah partai yang berbasis agama (Islam), meski kini partai itu sudah semakin dipertanyakan legalitas pemakaian asasnya.

Sebetulnya apa yang terjadi dalam kaitan mayoritas dan minoritas di Indonesia saat ini hanyalah lanjutan sejarah bangsa sejak zaman kolonial belaka. Sejarah telah menukilkan bahwa mayoritas adalah sebuah potensi sekaligus masalah, tergantung kepada yang melihatnya, sebagaimana mungkin diidentifikasi sebagai kebodohan sekaligus kesombongan. Mayoritas adalah sebuah amarah sekaligus kelemah-lembutan. Semua tak lepas dari standar ganda penilaian, sebagaimana halnya minoritas tak lebih dari sebuah dosa besar sekaligus 
dari perspektif tertentu akan menjadi pahala tak terhingga bagi yang melihatnya seperti itu. Minoritas juga adalah penjajah sekaligus innovator yang berkarya. Minoritas adalah musuh sekaligus kawan yang begitu bermanfaat, tergantung situasi dan tema karyanya. Minoritas dan mayoritas adalah pentas kontestasi besar yang tak berkesudahan dan sekaligus pula sebagai bentuk laten dari potensi perbenturan bangsa.

Fakta yang cukup menyulitkan analisis ialah solidaritas sesama minoritas berbilang ketika agregasinya disederhanakan menjadi kolektivitas diametral berhadapan dengan agregasi kasar yang lain yang mungkin secara numerical memang bertampang jauh lebih besar. Perhatikanlah komunitas-komunitas kecil yang sesungguhnya secara temporal tiba pada sebuah tali pemicu solidaritas untuk menyuarakan apa yang mereka identifikasi sebagai hakhak yang tak diindahkan oleh komunitas yang mereka identifikasi sebagai mayoritas. Tetapi pada saatnya juga pasti akan tiba dan mungkin selamanya memang seperti itu, mereka adalah komunitas yang saling mengeliminasi pada tataran lain.

Katakanlah suara azan dari menara masjid yang sudah dilazimkan berpengeras suara karena perhitungan bahwa teritorial (sekeliling masjid) adalah berpopulasi mayoritas muslim. Akibat masalah kesenjangan ekonomi yang parah umat Islam secara umum mengalami penyusutan di wilayah ini karena tanah beserta rumah-rumah mereka secara berangsur beralih kepemilikan kepada yang pemodal, dan itu non-muslim. Negara yang berwatak kapitalis memang mempersilakan minoritas beroleh segalanya demi rumus klasik ekonomi Negara bernama pertumbuhan (growth). Nazir masjid dan jamaah yang berangsur menyusut sama sekali tak menyadari bahwa akhirnya mereka sudah terkepung menjadi minoritas oleh tetangga-tetangga minoritas mereka yang kini sudah menjadi mayoritas. Peruntuhan masjid atas nama modal pun kerap terjadi di kota-kota besar seperti Medan, dan pemerintah mestinya bertanggungjawab sepenuhnya.

Kisah tragis lain adalah kasus semisal pembakaran sejumlah rumah ibadah di Tanjungbalai. Seseorang telah datang berkali-kali ke masjid untuk memrotes pengeras suara yang selalu mengumandangkan azan. Berani betul dia. Rakyat tak dapat memahami keberanian itu dan akhirnya memberi jawaban yang lain. Terjadilah kerusuhan sosial. Berdasarkan catatan sejarah, kejadian besar itu bukan yang pertama. Besok dan lusa, kalau begitu, hal yang sama pasti akan terjadi lagi. Apa pangkal masalah sesungguhnya? Selagi tak menemukan akar masalah, kita tak akan pernah tiba pada solusi yang benar. Menembaki orang-orang yang protes untuk sebagian orang adalah terapi jitu, sebagaimana pernah diterapkan di kampung Nelson Mandela yang legendaris itu. Tetapi ada hal yang tak pernah dipikirkan serius oleh pemnberi perintah tembak. Peluru itu pun akhirnya pasti akan bernurani juga setelah sekian kali dimuntahkan dari senapang yang digenggam gagah oleh seorang yang hidup dan matinya dijamin oleh Negara berdasarkan pajak yang dikutip dari rumah-rumah rakyat.

Negara telah gagal, atau sebetulnya berhasil dibajak untuk memihaki minoritas. Anda akan segera menyanggah, mana ada agama yang mengajarkan kebringasan? Islam itu kan rahmatan lil alamin, kok ada orang yang tega membakar rumah ibadah orang lain? Anda sudah sangat betul, tetapi sangat salah dalam memahami tugas utama bangunan sistem kebangsaan dan kenegaraan. Akan ada orang naïf lainnya yang akan mengonfrontasikan masalah ini dengan nilai Pancasila dan membumbuinya lagi dengan ajaran kebhinnekaan, pluralitas, toleransi dan lain sebagainya. Mungkin juga ia akan mengutip ayat-ayat dari kitab suci di luar konteks. Tetapi semua itu adalah argumen-argumen bernada kolonial yang juga pernah diterima oleh si Pitung, si Jiih, Sisingamangaraja dan juga Naga Bonar pada zamannya. Pancasila yang mana yang dapat membela keberadaan istimewa segelintir orang 
$(0,2 \%)$ yang menguasai $74 \%$ lahan di seluruh negeri? Ajaran kebhinnekaan mana yang dapat dijadikan apologi untuk mengistimewakan orang-orang ini? Ayat-ayat dari kitab suci mana yang menganggap pengistimewaan segelintir orang menjadi tugas utama Negara? Maka curigailah pemegang amanah di sebuah negeri. Jangan berhenti memotivasi mereka untuk segera kembali ke jalan yang benar, ke cita-cita kemerdekaan bangsa dan kejujuran yang diprasyaratkan oleh nilai-nilai universal.

Tetapi hak-hak normatif yang seyogianya dijamin sepenuhnya oleh Negara akan kalah dan dikalahkan oleh mainstream opini public. Indonesia mengalaminya berulangkali dalam eskalasi yang turun dan naik. Curigailah siapa pemilik media mainstream yang menjejali pendapat-pendapat miring menjadi kebenaran. Di sinilah Rocky Gerung sangat benar ketika mengemukakan pendapat bahwa penistaan atas nama hoax sekali pun sumbernya bukan dari mana-mana, kecuali dari pihak yang lebih berkuasa dan memiliki segalanya (uang, teknologi, media dan bedil).

Dilema besar mayoritasisme dan minoritasisme juga telah menjelaskan begitu sempurna kasus jilbab di sekolah sebagai kebutuhan syar'I kaum muslimin yang, dengan eskalasi pandangan politik tertentu, pernah menjadi masalah besar. Jika bukan karena

kekuatan politik (struktural) tertentu, mustahil kejadian buruk seperti ini terjadi. Pikirkanlah kembali apa yang terjadi di Bali yang seharusnya tak mempertinggi posisi Pecalang sebagai premus interpares di atas Negara ketika Hindu akan nyepi. Ini sebuah kekalahan telak Negara.

Hal yang sengaja kau kaburkan ialah bahwa persoalan minoritas juga terkait dengan kekuasaan dan intervensi asing terhadap kedaulatan negara. Dengan sadar Saba Mahmood berkata bahwa apa yang terjadi di Turki dan Mesir adalah contoh dari intervensi asing dengan isu religious freedom. Perlakuan dan perlindungan khusus terhadap minoritas di Turki merupakan sikap yang resmi diambil negara tanpa adanya dikte dan intervensi asing ketika negara itu kuat. Namun, ketika kekuatan Turki melemah, isu ini hanya menjadi alat permainan asing.

"When the Ottoman Empire was strong it was able to accommodate these pressures without compromising its sovereignty, but once Ottoman power started to decline it was unable to resist Western European incursions on behalf of the Ottoman Christian population" (Saba Mahmood, 2012, p 421).

Saya berterimakasih ketika akhirnya Muhammad Najib Burhani menguak fakta bahwa dalam pengelolaan isu mayoritas vs minoritas berbagai LSM atau NGO atau CSO bergerak karena mendapatkan dana atau instruksi asing. Mereka merupakan puppet atau wayang atau bidak pion dari kekuasaan asing atau kepentingan asing.

Keberadaan mereka dan kekuasaan asing itu sangat mengganggu kedaulatan negara dalam mengatur persoalan keberagamaan. Padahal kita semua tahu, termasuk mereka yang dibiayai dan di indtruksikan oleh asing itu, kebebasan beragama di Indonesia jauh lebih baik daripada yang terjadi di negeri-negeri peneriak yang tak kstaria itu. Bukankah ketika isu minoritas mengenai dunia Islam banyak LSM/NGO dan CSO yang berteriak dan ketika terjadi di Barat atau negara non-Muslim, mereka semua seperti menjadi bisu? 
Saya teringat percakapan saya dengan Lance Castle di UGM beberapa tahun lalu. Katanya, sebelum Anda membaca buku Sipongki Na Ngolngolan karya Mangaradja Onggang Parlindungan itu, sebaiknya Anda bawa dulu orang ini ke psikiater. Buku penyesatan ini adalah karya tipikal yang sejak lama diproduksi untuk memusuhi Islam. Hingga tahun 1950 saja lebih dari 60.000 judul buku telah diterbitkan hanya untuk mencaci-maki Islam (Time, No 16 Tahun 1979).

Karena itu, jika Anda menemukan deretan papan bunga yang bagus-bagus untuk AhokDjarot, di halaman rumah Anda, yakinlah mereka sedang memainkan pembenturan ideologi mayoritasisme dengan ideologi minoritasisme melalui pembentukan opini melawan hakhakmu menegakkan perintah Al-Maidah ayat 51 dan ayat-ayat lain yang selaras dengan itu. Tugas Anda sederhana saja, beri mereka pengertian tentang Pancasila, Bhinneka Tunggal Ika dan demokrasi. Katakan bahwa di Amerika yang menjadi ompung demokrasi dunia itu pun masih dianggap betul prinsip "my faith is my vote". Bahkan di Indonesia yang berpancasila ini pun partai agama diakui keberadaannya. Bisikkan dengan halus dan santun: "Jangan salahkan siapa-siapa jika partai yang mengatasnamakan agamamu pun sudah bubar berantakan".

Penulis dosen FISIP UMSU. Koordinator Umum Pengembangan Basis Sosial Inisiatif \& Swadaya ('nBASIS) 